\title{
Próby wyznaczenia parametrów geomechanicznych i anizotropii Thomsena w węglu kamiennym z obszaru Górnośląskiego Zagłębia Węglowego
}

\section{Attempts to determine the geomechanical and Thomsen's anisotropy parameters of coal from Upper Silesian Coal Basin area}

\author{
Rafał Moska, Mateusz Masłowski \\ Instytut Nafty i Gazu - Państwowy Instytut Badawczy
}

\begin{abstract}
STRESZCZENIE: W ostatnich latach nastąpił wzrost zainteresowania polskiego przemysłu naftowo-gazowniczego złożami niekonwencjonalnymi, w tym zasobnymi w metan pokładami węgla (CBM). Aby uwolnić zawarty w formacji węglowej gaz, wymagane jest wykonanie zabiegu hydraulicznego szczelinowania horyzontu produktywnego, udostępnionego najczęściej odwiertem kierunkowym z powierzchni. Kluczowymi informacjami wymaganymi przy projektowaniu zabiegu hydraulicznego szczelinowania są właściwości geomechaniczne ośrodka definiowane przez moduły sprężystości. Moduły te ze względu na anizotropię ośrodka zmieniają się w zależności od kierunku pomiaru. Artykuł ten opisuje eksperymentalną próbę wyznaczenia parametrów anizotropii Thomsena w próbce węgla kamiennego z obszaru GZW. Badanie wykonano metodą trójrdzenikową Vernika: rdzeniki były wycięte z bloku węgla: równolegle, prostopadle oraz pod kątem $45^{\circ}$ do osi symetrii VTI. Badania ultradźwiękowe wykonano w temperaturze otoczenia, przy ciśnieniu uszczelnienia $10 \mathrm{MPa}$. Prędkość fal P i S zawierała się w przedziale odpowiednio 2,378-2,430 m/s i 1,261-1,328 m/s, przy czym fale najszybciej propagowały w próbce wyciętej równolegle do uwarstwienia. Uzyskane współczynniki anizotropii poprzecznej $K$ i azymutalnej $A$ bliskie jedności oraz parametry Thomsena $\varepsilon, \gamma, \delta$, zbliżone do zera, pozwalają stwierdzić, że blok węgla charakteryzował się niewielką anizotropią spowodowaną warstwowaniem (laminacją) poziomym oraz mikropęknięciami, zgodnymi z kierunkiem warstwowania. Zostały również wyznaczone dynamiczne moduły sprężystości, których przedziały wartości odpowiadają danym literaturowym. Niskie moduły Younga $(5,3-5,7 \mathrm{GPa})$ oraz wysokie współczynniki Poissona $(0,29-0,30)$ sugerują, że omawiana próbka węgla powinna być zaliczana do skał o niskiej podatności na hydrauliczne szczelinowanie (wskaźnik brittleness 22,7-23,9\%). Jednakże duża ilość spękań oraz słaba zwięzłość próbki, sprzyjające otwieraniu się szczelin podczas zabiegu, pozwalają stwierdzić, że ta skała nie powinna być traktowana jako plastyczna w klasycznym tego słowa rozumieniu.
\end{abstract}

Słowa kluczowe: parametry sprężystości, anizotropia Thomsena, węgiel kamienny, Górnośląskie Zagłębie Węglowe, hydrauliczne szczelinowanie.

\begin{abstract}
A growing interest in unconventional gas resources including coal bed methane (CBM) has been observed in Poland in recent years. CBM resources require hydraulic fracturing to gain the hydrocarbons. Elastic parameters of the resource rock are one of the keys to effective fracking. If the deposits are anisotropic, these parameters may vary depending on the direction of the measurement. This paper describes ultrasonic laboratory measurements of coal core samples from Upper Silesian Coal Basin, conducted in order to designate Thomsen anisotropy parameters. The tests were carried out using Vernik method (three core plugs: parallel, perpendicular and at $45^{\circ}$ angle to VTI symmetry axis). Measurements were conducted at ambient temperature and confining pressure of $10 \mathrm{MPa}$. The velocities of the $\mathrm{P}$ - and $\mathrm{S}$ - wave fell within the range from 2.378 to $2.430 \mathrm{~m} / \mathrm{s}$ and from 1.261 to $1.328 \mathrm{~m} / \mathrm{s}$, respectively. The velocities of $\mathrm{P}$ - and $\mathrm{S}$ - waves were the highest in parallel sample and the lowest in perpendicular plug. Obtained anisotropy factors $K$ and $A$ close to unity and Thomsen parameters close to zero let us state weak anisotropy caused probably by bedding (lamination) and microcracks along to the lamination. Dynamic elastic moduli were also calculated from velocities. Significantly low values of Young's modulus (5.3-5.7 GPa), and high values of Poisson's ratio (0.29-0.30) indicate that this sample should be considered as a hard to frack rock (brittleness index 22.7-23.9\%). The large number of cracks in the samples facilitates, however, opening of the inducted fractures during treatment. This allows us to state that this rock should not be treated as typical plastic rock in classical meaning.
\end{abstract}

Key words: elastic parameters, Thomsen anisotropy, coal, Upper Silesian Coal Basin, hydraulic fracturing.

Autor do korespondencji: R. Moska, e-mail:rafal.moska@inig.pl

Artykuł nadesłano do Redakcji: 28.06.2019 r. Zatwierdzono do druku 23.10.2019 r. 


\section{Wstęp}

W ostatnich latach nastąpił wzrost zainteresowania polskiego przemysłu naftowo-gazowniczego złożami niekonwencjonalnymi, w tym zasobnymi w metan pokładami węgla (CBM). Prognozowane zasoby CBM w Górnośląskim Zagłębiu Węglowym, według ekspertów PIG - PIB, wynoszą $170 \mathrm{mld} \mathrm{m}^{3}$ gazu, przy czym całkowity potencjał zasobowy GZW to około 230-350 $\mathrm{mld} \mathrm{m}^{3}$ (Jureczka, b.d.). Eksploatacja złóż niekonwencjonalnych, w tym CBM, jest zdecydowanie bardziej skomplikowana niż złóż w klasycznym rozumieniu. Metan występuje w węglu w postaci: zaadsorbowanej w mikroporach o średnicy poniżej $2 \mathrm{~mm}$, zatrzymany w matrycy węglowej - związany słabymi wiązaniami van der Waalsa na powierzchni węgla, w postaci wolnego gazu w szczelinach i spękaniach oraz jako gaz rozpuszczony w wodzie w węglu (Gonet et al., 2010). Aby uwolnić zawarty gaz, wymagane jest wykonanie zabiegu hydraulicznego szczelinowania horyzontu produktywnego, udostępnionego odwiertem pionowym lub kierunkowym z powierzchni (Kasza, 2019). W listopadzie 2016 roku przeprowadzono pierwsze próbne szczelinowanie w odwiercie Gilowice-2H, udostępniającym pokład węgla 510 w okolicach Brzeszcz w województwie małopolskim. Zabieg zakończył się sukcesem, a podczas testów w październiku i listopadzie 2017 roku odnotowano dopływ gazu wysokometanowego na poziomie $5200-5400 \mathrm{~m}^{3} \mathrm{dzien}$ nie (PIG - PIB i PGNiG, 2017). Prace na złożu Gilowice są obecnie kontynuowane, a kolejny zabieg szczelinowania miał miejsce pod koniec 2018 roku na odwiercie Gilowice-4H (Kroplewski et al., 2019).

Jednymi z kluczowych informacji wymaganych przy projektowaniu zabiegu hydraulicznego szczelinowania są właściwości geomechaniczne ośrodka skalnego definiowane przez moduły sprężystości. Moduły ze względu na anizotropię zmieniają się w zależności od kierunku pomiaru. Rosnące zainteresowanie pozyskiwaniem metanu z pokładów węgla, udostępnianych dzięki zabiegom szczelinowania, spowodowało, że badania anizotropii sprężystości w węglach kamiennych znajdują się obecnie w kręgu zainteresowań coraz większej grupy naukowców.

\section{Anizotropia właściwości sprężystych w skałach}

Anizotropia właściwości sprężystych oznacza ich zmienność wraz ze zmianą kierunku pomiaru. Większość skał posiada anizotropię słabą lub umiarkowaną, a niektóre minerały również silną (Thomsen, 1986). Najważniejsze źródła anizotropii właściwości sprężystych w skałach to: a) obecność orientowanych pęknięć, szczelin i mikroszczelin; b) warstwowanie, np. cienkie warstewki w skałach ilasto-mułowcowych; c) tekstura skały - preferencyjna orientacja anizotropowych minerałów (Ciechanowska i Zalewska, 2006). Najczęściej wykorzystywanymi parametrami opisującymi anizotropię właściwości sprężystych skał są parametry Thomsena. Teoria Thomsena (1986) opisuje szczególny, uproszczony rodzaj modelu z heksagonalną symetrią (vertical transverse isotropy) VTI lub TIV. Jest to model dla ośrodków poprzecznie izotropowych, czyli takich, w których oś symetrii przebiega pod kątem $90^{\circ}$ do płaszczyzn warstwowania. Modelem tym można opisać zatem większość skał osadowych posiadających płasko-równoległe warstwowanie lub laminację, będących w kręgu zainteresowania geologii naftowej.

Anizotropia właściwości sprężystych opisywana parametrami Thomsena była dotychczas szeroko przedstawiana w literaturze zarówno zagranicznej, jak i krajowej. Opracowania dotyczyły przede wszystkim skał ilasto-mułowcowych o teksturze łupkowej, ale zajmowano się także m.in. piaskowcami, skałami węglanowymi, anhydrytami i innymi skałami (np. Lo et al., 1985; Yin, 1992; Wang, 2002b; Zalewska et al., 2009; Sone i Zoback, 2013; Bała, 2018). Dane wykorzystywane do badań pochodziły zarówno z testów laboratoryjnych, jak i z profilowań akustycznych geofizyki wiertniczej.

\section{Badania ultradźwiękowe w próbkach węglowych}

W przeszłości wykonywano badania ultradźwiękowe na próbkach różnego rodzaju węgli, związane m.in. z: wpływem ciśnienia i nasycenia wodą na moduły sprężystości (Yu et al., 1993), zależnościami modułów sprężystości od parametrów petrograficznych (Kumar et al., 2015), związkami z poziomem refleksyjności witrynitu (Garcia-Gonzalez i Towle, 2006) oraz mikrostrukturami wewnętrznymi (Qiong et al., 2016). Mierzono również różnie definiowane współczynniki anizotropii w węglach (np. Wu et al., 2015), a także parametry anizotropii Thomsena w węglach (np.: Qiuliang i De-hua, 2008; Morcote et al., 2010). Węgle kamienne z obszaru GZW nie były dotychczas powszechnie przedmiotem tego rodzaju badań. Prawdopodobnie wynika to między innymi z niewielkiego zainteresowania tą gałęzią geomechaniki w Polsce (co zmienia się dopiero w ostatnich kilku latach - projekt Gilowice), jak również z trudności w wypreparowaniu próbek z mocno spękanej calizny skalnej. Ich słaba konsolidacja może powodować bardzo wysokie tłumienie fali (obniżenie amplitudy sygnału użytecznego do poziomu szumu aparatury), przez co wyznaczenie czasów pierwszych wstąpień może być, w niektórych przypadkach, bardzo utrudnione lub niemożliwe. Stąd też konieczne staje się wycinanie dużej liczby próbek, przy czym tylko z nielicznych uzyskuje się wiarygodne rezultaty pomiarów. 


\section{Słaba anizotropia opisywana parametrami Thomsena}

W najprostszym przypadku anizotropii z heksagonalną symetrią (model vertical transverse isotropy) macierz tensora sztywności ma 5 niezależnych składowych spośród 12 niezerowych. Są to: $\mathrm{C}_{11}, \mathrm{C}_{33}, \mathrm{C}_{44}, \mathrm{C}_{66} \mathrm{i}_{13}$ (Wang, 2002b; Ciechanowska i Zalewska, 2006). Do wyznaczenia tych składowych wykorzystywane są prędkości fal ultradźwiękowych P i S, mierzone w określonych kierunkach. Składowe te, oprócz $\mathrm{C}_{13}$, powstają z zestawienia prędkości fal oraz gęstości objętościowej, natomiast składowa $\mathrm{C}_{13}$ jest obliczana matematycznie i niezbędne są w jej przypadku trzy składowe, gęstość objętościowa oraz prędkość propagacji fali P pod kątem $45^{\circ}$ do osi symetrii:

$$
\begin{aligned}
& \mathrm{C}_{33}=\rho V_{p_{y}}^{2} \\
& \mathrm{C}_{11}=\rho V_{p_{x}}^{2} \\
& \mathrm{C}_{44}=\rho V_{s_{y}}^{2} \\
& \mathrm{C}_{66}=\rho V_{s_{x}}^{2}
\end{aligned}
$$

$C_{13}=\left[\frac{\left(4 \rho V_{p_{z}}^{2}-C_{11}-C_{33}-2 C_{44}\right)^{2}-\left(C_{11}-C_{33}\right)^{2}}{4}\right]^{\frac{1}{2}}-C_{44}$

gdzie:

$V_{p_{y}}, V_{p_{x}}-$ prędkość fali podłużnej pomierzona odpowiednio prostopadle i równolegle do uwarstwienia,

$V_{s_{y}}, V_{s_{x}}$ - prędkość fali poprzecznej pomierzona odpowiednio prostopadle i równolegle do uwarstwienia,

$V_{p_{z}}-$ prędkość fali podłużnej pomierzona pod kątem $45^{\circ}$ do osi symetrii.

Dla ośrodka izotropowego przyjmuje się, że $\mathrm{C}_{11}=\mathrm{C}_{33}$ $\mathrm{i}_{44}=\mathrm{C}_{33}$.

Dla ośrodka anizotropowego: $\mathrm{C}_{11}>\mathrm{C}_{33} \mathrm{i}_{66}>\mathrm{C}_{44}$, ponieważ fale $\mathrm{P}$ i S propagują $\mathrm{z}$ większymi prędkościami zgodnie z kierunkiem uwarstwienia.

Parametry Thomsena opisujące słabą anizotropię można wyrazić w następujący sposób (Wang, 2002b; Zalewska et al., 2009):

$$
\begin{gathered}
\varepsilon=\frac{\mathrm{C}_{11}-\mathrm{C}_{33}}{2 \mathrm{C}_{33}} \\
\gamma=\frac{\mathrm{C}_{66}-\mathrm{C}_{44}}{2 \mathrm{C}_{44}} \\
\sigma=\frac{\mathrm{C}_{33}}{\mathrm{C}_{44}}(\varepsilon-\delta) \\
\eta=\frac{\varepsilon-\delta}{1+2 \delta} \\
\delta=\frac{\left(\mathrm{C}_{13}+\mathrm{C}_{44}\right)^{2}-\left(\mathrm{C}_{33}+\mathrm{C}_{44}\right)^{2}}{2 \mathrm{C}_{33}\left(\mathrm{C}_{33}+\mathrm{C}_{44}\right)^{2}}
\end{gathered}
$$

gdzie:

$\varepsilon-$ intensywność anizotropii fali $\mathrm{P}$,

$\gamma$ - intensywność anizotropii fali $\mathrm{S}$,

$\sigma$ - wpływ zróżnicowania impedancji akustycznej dla fal P i S na intensywność zjawiska anizotropii fali $\mathrm{P}$,

$\eta$ - wpływ izotropii poprzecznej ośrodka na wielkość anizotropii fali $P$,

$\delta$ - wpływ izotropii poprzecznej na amplitudę fali P.

Na podstawie danych opublikowanych przez Thomsena (1986) - Zalewska i inni (2009) opisują, że słaba anizotropia oznacza, że $\varepsilon, \delta, \gamma<<1$, natomiast umiarkowana, że $\varepsilon, \delta, \gamma<0,2$.

\section{Przygotowanie próbek do badań anizotropii właściwości sprężystych}

Ważnym zagadnieniem przygotowawczym przy wyznaczaniu anizotropii właściwości sprężystych w badaniach laboratoryjnych jest wypreparowanie odpowiedniej próbki. Jako że badania takie wykonywane są od lat, kilku badaczy opracowało swoje własne sposoby przygotowania próbek. Yin (1992) zasugerował preparowanie próbek w kształcie wielościanów foremnych. Przetworniki piezoelektryczne są wówczas przykładane do ścian figury. Taka metoda preparowania jest stosunkowo skomplikowana, wymaga ręcznego docinania próbki, często szlifowania dla uzyskania gładkiej powierzchni oraz kontrolowania równoległości ścian figury. Próbkę taką trudno jest nasycić mediami oraz przebadać w złożowych warunkach ciśnienia. Vernik i Nur (1992), Vernik (1993), Vernik i inni (1994), zaproponowali wycinanie z calizny skalnej trzech rdzeników: po jednym prostopadle, równolegle i pod kątem $45^{\circ}$ do powierzchni uwarstwienia. Przetworniki przykładane są wówczas do czoła rdzeników. Sposób wycinania w tej metodzie, dzięki użyciu rdzeniówki i przycinarki czołowej, jest znacznie prostszy i mniej czasochłonny. Rdzeniki zazwyczaj nie wymagają dodatkowego ręcznego szlifowania dla uzyskania gładkiej powierzchni. Posiadając stosunkowo prosto zbudowaną komorę rdzeniową, można również wykonać pomiar w złożowych warunkach ciśnienia (konwencjonalne trójosiowe ściskanie) i temperatury, przy nasyceniu mediami złożowymi. Metoda trójrdzenikowa była wykorzystywana m.in. w badaniach skał ilasto-mułowcowych i anhydrytów (Ciechanowska i Zalewska, 2006), utworach czerwonego spągowca (Zalewska et al., 2009), jak również w badaniach węgla kamiennego (Qiuliang i De-hua, 2008). Morcote i inni (2010), badając węgle kamienne, również korzystali z tej metody, jednakże nie dysponowali rdzenikiem wyciętym pod kątem $45^{\circ}$ względem osi symetrii, przez co nie obliczyli parametru $\delta$. Wang (2002a) zmodyfikował powyższą metodę, wykorzystując tylko jeden rdzenik o średnicy $51 \mathrm{~mm}$ 
i długości 25-100 mm wycięty równolegle do warstwowania. Przetworniki są w takim przypadku przykładane zarówno do czoła rdzenika, jak i do jego boków w osi prostopadłej do warstwowania oraz pod kątem $45^{\circ}$ do tej osi. Metoda ta pozwala zaoszczędzić czas, materiał rdzeniowy przy wycinaniu, a przeprowadzenie badania w warunkach otoczenia (rdzeń nienasycony, ciśnienie atmosferyczne) jest ułatwione. $Z$ drugiej strony próbka taka wymaga stosunkowo skomplikowanej komory rdzeniowej do pomiarów w warunkach złożowych.

\section{Próbka użyta do badań}

Do badań został pobrany blok węgla kamiennego z KWK Mysłowice-Wesoła. Blok posiadał makroskopowo widoczne uwarstwienie poziome, przewarstwienia macerałów oraz spękania, głównie w kierunku równoległym do płaszczyzn warstwowania. $Z$ bloku zostały wycięte trzy rdzeniki o średnicy 1 cala i długości podanej w tabeli 2. Zgodnie z metodyką pomiarów zaproponowaną przez Vernika (1993) wycięto jeden rdzeń równolegle do osi symetrii VTI, jeden prostopadle do niej i jeden pod kątem $45^{\circ}$ (rys. 1, 2).

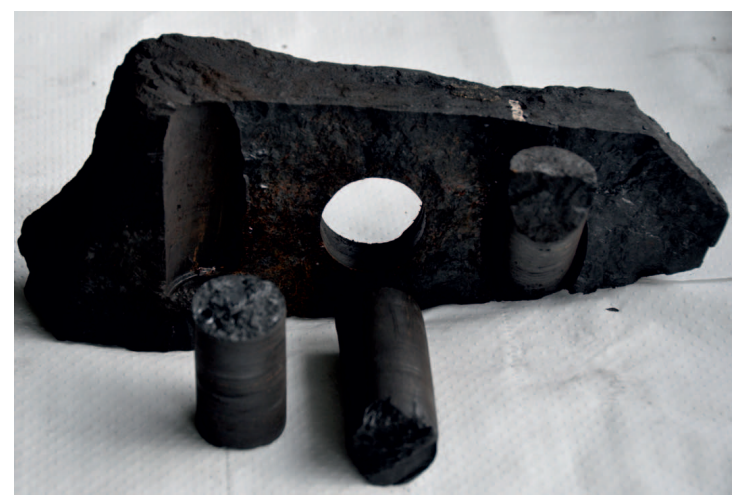

Rys. 1. Rdzeniki z węgla kamiennego użyte do badań

Fig. 1. Coal samples used for measurements

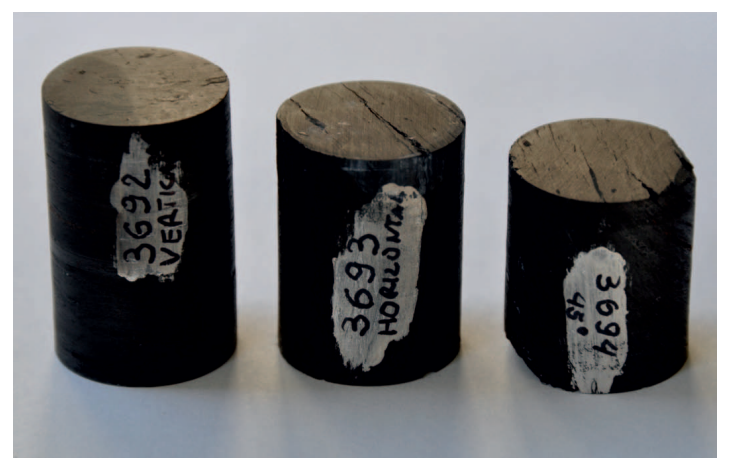

Rys. 2. Rdzeniki z węgla kamiennego użyte do badań po obróbce powierzchni czołowych. Na próbce 3693 oraz 3694 widoczne spękania równoległe do uwarstwienia

Fig. 2. Coal samples after top and bottom surface preparation. Cracks parallel to bedding planes are visible on samples 3693 and 3694

\section{Metodyka badań}

W pierwszej kolejności wyznaczono współczynniki porowatości efektywnej oraz gęstości objętościowe przy użyciu porozymetru helowego HGP-100. Badania ultradźwiękowe wykonywano w następujących warunkach: temperatura otoczenia wynosiła $23^{\circ} \mathrm{C}$, nie nasycano przestrzeni porowej rdzeni, tak więc w efektywnej przestrzeni porowej znajdowało się powietrze. Ciśnienie uszczelnienia układu konwencjonalnego trójosiowego ściskania wynosiło 9,72 MPa (1410 psi), co odpowiada ciśnieniu hydrostatycznemu na głębokości pobrania próby węgla. Pomiary wykonywano przy użyciu urządzenia Vinci AVS 700. Częstotliwość pracy przetworników wynosiła $500 \mathrm{MHz}$. Dokładność uzyskiwanych wyników przedstawiono w tabeli 1.

Tabela 1. Dokładność uzyskiwanych wyników podczas badań na urządzeniu AVS 700

Table 1. Accuracy of measurements using AVS 700 device

\begin{tabular}{|l|c|}
\hline \multicolumn{1}{|c|}{ Parametr } & Dokladność \\
\hline \hline Temperatura $\left[{ }^{\circ} \mathrm{C}\right]$ & 0,1 \\
\hline Ciśnienie [psi] & 1 \\
\hline Czas propagacji fali $[\mu \mathrm{s}]$ & 0,1 \\
\hline Prędkość propagacji $[\mathrm{m} / \mathrm{s}]$ & 1 \\
\hline Współczynnik Poissona $[-]$ & 0,01 \\
\hline Moduły sprężystości $[\mathrm{GPa}]$ & 0,1 \\
\hline
\end{tabular}

Pomierzono czasy przejścia fal P i S przez każdy z trzech rdzeników. Na podstawie czasów time of flight wyznaczono prędkości fal. Z prędkości fal obliczono dynamiczne moduły sprężystości, dla trzech kierunków pomiaru, przy wykorzystaniu wzorów (Fjar et al., 2008):

$$
\begin{gathered}
v=\frac{\frac{1}{2}-\left(\frac{V_{S}}{V_{P}}\right)^{2}}{1-\left(\frac{V_{S}}{V_{P}}\right)} \\
E=\rho \frac{V_{P}^{2}(1+v)(1-v)}{(1-v)} \\
G=\rho V_{S}^{2} \\
K=\rho V_{P}^{2}-\frac{3}{4} V_{S}^{2}
\end{gathered}
$$

gdzie:

$V_{P}-$ prędkość fali $\mathrm{P}[\mathrm{m} / \mathrm{s}]$,

$V_{S}$ - prędkość fali S [m/s],

$\rho$ - gęstość objętościowa $\left[\mathrm{g} / \mathrm{cm}^{3}\right]$,

$v$-współczynnik Poissona [bezwymiarowy],

$E$ - moduł Younga [Pa],

$G$ - moduł odkształcenia postaci (ścinania) [Pa],

$K$ - moduł odkształcenia objętości [Pa]. 
Z wyznaczonych prędkości fal obliczono współczynniki anizotropii poprzecznej $K$ oraz anizotropii azymutalnej $A$ (Ciechanowska i Zalewska, 2006):

$$
\begin{aligned}
& K_{1}=\frac{V_{P} Y}{V_{P} X} \\
& K_{2}=\frac{V_{S} Y}{V_{S} X} \\
& A_{1}=\frac{V_{P} Y}{V_{P} Z} \\
& A_{2}=\frac{V_{S} Y}{V_{S} Z}
\end{aligned}
$$

gdzie:

$V_{P}, V_{S}$ - prędkości fali podłużnej i poprzecznej.

Oś pomiaru względem płaszczyzn uwarstwienia: $X$ - równoległa, $Y$ - prostopadła, $Z$ - pod kątem $45^{\circ}$.

Następnie wyznaczono 5 niezależnych składowych elastycznych: $\mathrm{C}_{33}, \mathrm{C}_{11}, \mathrm{C}_{44}, \mathrm{C}_{66}, \mathrm{C}_{13}$ oraz 5 parametrów Thomsena (1986): $\varepsilon, \gamma, \sigma, \eta, \delta$ sposobem opisanym we wstępie niniejszej pracy (Wang, 2002b; Ciechanowska i Zalewska, 2006).

Obliczono również wskaźnik kruchości brittleness na podstawie uzyskanych dynamicznych modułów Younga i Poissona według następującej metody (Grieser i Bray, 2007):

$$
\begin{gathered}
Y M_{B R I T}=\frac{Y M-Y M \_ \text {min }}{Y M \_ \text {max }-Y M_{-} \min } \cdot 100 \% \\
P R_{B R I T}=\frac{P R-P R_{-} \max }{P R_{-} \min -P R_{-} \max } \cdot 100 \%
\end{gathered}
$$

$$
\text { BRITTLENESS } S_{\text {Grieser \& Bray, } 2007}=\frac{Y M_{B R I T}+P R_{B R I T}}{2}
$$

gdzie:

$Y M_{B R I T}$ - kruchość z modułu Younga,

$P R_{B R I T}$ - kruchość ze współczynnika Poissona,

$Y M$ - pomierzony moduł Younga,

$P R$ - pomierzony współczynnik Poissona,

$Y M \_$min, $Y M \_$max, $P R \_$min, $P R \_$max - punk-

ty odniesienia, tj. stałe określające minimalne i maksymalne wartości modułu Younga i współczynnika Poissona spotykane w skałach osadowych. Na potrzeby pracy przyjęto $Y M \_\min =0[\mathrm{GPa}]$, $Y M_{-} \max =100[\mathrm{GPa}], P R_{-} \min =0[-]$, $P R \_$max $=0,5[-]$. Wartości $Y M \_$min i $P R \_$min równe 0 są wartościami umownymi, sugerowanymi przez Griesera i Braya (2007).

\section{Wyniki badań i dyskusja}

W tabelach 2-5 i na rysunku 3 zamieszczono wyniki badań.

Laboratoryjne badania ultradźwiękowe węgli kamiennych pochodzących z GZW nie były dotychczas powszechnie wykonywane. W polskiej, jak i zagranicznej literaturze nie są dostępne dane umożliwiające bezpośrednie porównanie do wyników niniejszej pracy. Autor zadecydował więc, aby porównać uzyskane wyniki z dostępnymi wynikami badań ultradźwiękowych węgli kamiennych, wykonywanych w zbliżonych warunkach.

Wszystkie trzy rdzeniki charakteryzowały się prawie identycznymi współczynnikami porowatości efektywnej oraz gęstościami objętościowymi (tab. 2), przez co można wykluczyć wpływ tych wielkości na wynik badania anizotropii.

Fale najszybciej propagują w kierunku równoległym do warstwowania oraz spękań (próbka wycięta równolegle $V_{P}=2430 \mathrm{~m} / \mathrm{s}, V_{S}=1328 \mathrm{~m} / \mathrm{s}$ ). W próbce wyciętej pod kątem $45^{\circ}$ do osi symetrii prędkości fal są niższe odpowiednio o $22 \mathrm{~m} / \mathrm{s}(0,5 \%)$ i $30 \mathrm{~m} / \mathrm{s}(2,3 \%)$. W próbce wyciętej prostopadle prędkości są niższe odpowiednio o $52 \mathrm{~m} / \mathrm{s}(2,1 \%)$ i $67 \mathrm{~m} / \mathrm{s}$ (5,0\%). Stosunek prędkości fali P do S zawiera się w przedziale od 1,83 dla próbki wyciętej równolegle, do 1,89 dla próbki prostopadłej. Przedziały prędkości fal są zatem porównywalne do wartości przytaczanych w literaturze (tab. 6).

Uzyskane dynamiczne moduły sprężystości są zbliżone do wartości literaturowych dla węgli kamiennych bitumicznych (tab. 6). Wyznaczony na ich podstawie parametr kruchości brittleness jest niski (22,7-23,9\%), co według aktualnie używanych definicji kruchości dla skał w przemyśle naftowym (np. Grieser i Bray, 2007; Rickman et al., 2008, Kasza, 2013) oznacza, że jest to skała plastyczna o niskiej podatności na szczelinowanie (rys. 3). Jednakże bardzo duża ilość spękań oraz słaba konsolidacja w węglach kamiennych, która jest powodem niskich prędkości propagacji fal, a co za tym idzie - niskich modułów $E$ i wysokich współczynników $v$, sprzyja otwieraniu się szczelin podczas zabiegu w dużej objętości górotworu, co
Tabela 2. Podstawowe parametry badanych próbek

Table 2. Parameters and features of measured samples

\begin{tabular}{|c|c|c|c|c|c|}
\hline $\begin{array}{c}\text { Nr próbki } \\
\text { i kierunek } \\
\text { wycięcia }\end{array}$ & Średnica Ø & Długość $\boldsymbol{l}$ & Masa $\boldsymbol{m}$ & $\begin{array}{c}\text { Współczynnik } \\
\text { porowatości } \\
\text { efektywnej } \boldsymbol{p}\end{array}$ & $\begin{array}{c}\text { Gęstośćć } \\
\text { objętościowa } \boldsymbol{\rho}\end{array}$ \\
\cline { 2 - 6 } & {$[\mathbf{m m}]$} & {$[\mathbf{m m}]$} & {$[\mathbf{g}]$} & {$[\%]$} & {$\left[\mathbf{g} / \mathbf{c m}^{3}\right]$} \\
\hline \hline $\begin{array}{c}3692 \\
\text { prostopadle }\end{array}$ & 25,54 & 39,48 & 25,77 & 2,71 & 1,283 \\
\hline $\begin{array}{c}3693 \\
\text { równolegle }\end{array}$ & 25,52 & 34,27 & 22,50 & - & 1,267 \\
\hline $\begin{array}{c}3694 \\
45^{\circ}\end{array}$ & 25,51 & 29,98 & 19,47 & 2,71 & 1,283 \\
\hline
\end{tabular}


Tabela 3. Prędkości fal oraz moduły sprężystości badanych próbek

\begin{tabular}{|c|c|c|c|c|c|c|c|}
\hline \multirow{2}{*}{$\begin{array}{c}\text { Nr próbki } \\
\text { i kierunek } \\
\text { wycięcia }\end{array}$} & $V_{P}$ & $V_{S}$ & \multirow{2}{*}{$V_{P} / \boldsymbol{V}_{S}$} & $\begin{array}{c}\text { Wspólczynnik } \\
\text { Poissona } v\end{array}$ & $\begin{array}{c}\text { Moduł } \\
\text { Younga } \boldsymbol{E}\end{array}$ & $\begin{array}{c}\text { Moduł } \\
\text { ścinania } \boldsymbol{G}\end{array}$ & $\begin{array}{c}\text { Modul } \\
\text { odkształcenia } \\
\text { objętości } \boldsymbol{K}\end{array}$ \\
\cline { 2 - 6 } & {$[\mathrm{m} / \mathbf{s}]$} & {$[\mathrm{m} / \mathbf{s}]$} & & {$[-]$} & {$[G P a]$} & {$[\mathbf{G P a}]$} & {$[\mathrm{GPa}]$} \\
\hline \hline $\begin{array}{c}3692 \\
\text { prostopadle }\end{array}$ & 2378 & 1261 & 1,89 & 0,30 & 5,32 & 2,04 & 4,54 \\
\hline $\begin{array}{c}3693 \\
\text { równolegle }\end{array}$ & 2430 & 1328 & 1,83 & 0,29 & 5,77 & 2,24 & 4,51 \\
\hline $\begin{array}{c}3694 \\
45^{\circ}\end{array}$ & 2418 & 1298 & 1,86 & 0,30 & 5,61 & 2,16 & 4,62 \\
\hline
\end{tabular}

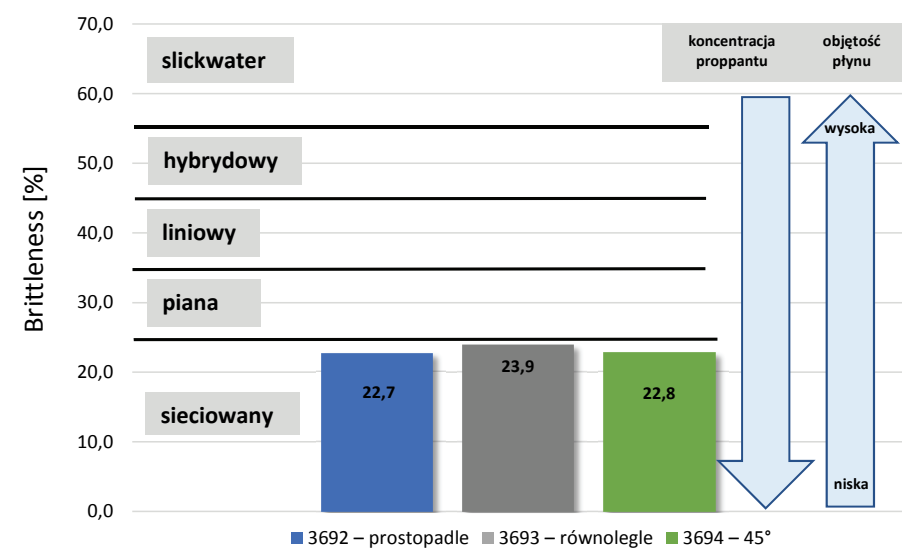

Rys. 3. Wskaźniki kruchości brittleness badanych próbek i odpowiadające im rodzaje cieczy szczelinujących (na podstawie: Kasza, 2013)

Fig. 3. Brittleness indexes of measured samples and corresponding fracturing fluids (based on Kasza, 2013)

Tabela 4. Współczynniki anizotropii badanych próbek

Table 4. Anisotropy factors of measured samples

\begin{tabular}{|c|c|c|c|}
\hline \multicolumn{3}{|c|}{ Współczynnik anizotropii } \\
\hline \multicolumn{2}{|c|}{ poprzecznej } & \multicolumn{2}{c|}{ azymutalnej } \\
\hline $\boldsymbol{K}_{\mathbf{1}}$ & $\boldsymbol{K}_{\mathbf{2}}$ & $\boldsymbol{A}_{\mathbf{1}}$ & $\boldsymbol{A}_{\mathbf{2}}$ \\
\hline \hline 0,979 & 0,950 & 0,983 & 0,971 \\
\hline
\end{tabular}

Table 3. Wave velocities and elastic moduli of measured samples

właściwościach wykonuje się zabiegi hybrydowe (Gilowice$2 \mathrm{H}$ i $4 \mathrm{H})$ (Kroplewski et al., 2019), wktórych naprzemienne tłoczenie płynów liniowych i sieciowanych pozwala na lepsze podsadzenie szczelin głównych. Literatura podaje, że w formacjach o wysokiej plastyczności (łupki o niskich modułach $E$ i wysokich v) zachodzi duże prawdopodobieństwo zjawiska embedment (wciskania ziaren podsadzki w ściany szczeliny po zabiegu) (Alramahi i Sundberg, 2012). Zjawisko to powoduje zmniejszenie rozwartości szczeliny, co przekłada się na spadek jej przewodności (Masłowski et al., 2019). Powyższe dane nie odnoszą się jednak do węgli kamiennych.

Małe zmiany w prędkościach fal w badanych próbkach przekładają się na współczynniki anizotropii poprzecznej i azymutalnej $K_{1,2}$ i $A_{1,2}$ zbliżone do jedności, co oznacza niewielki stopień anizotropii (tab. 4). Uzyskany współczynnik anizotropii Thomsena dla fali $\mathrm{P}(\varepsilon)$ jest bardziej zbliżony do zera niż współczynniki opisane w przytoczonej literaturze, co sugeruje, że badana próbka charakteryzowała się niższą anizotropią dla tej fali (tab. 6). Współczynnik $\gamma$ opisujący anizotropię fali S jest natomiast zbliżony do danych literaturowych. Można przypuszczać, że omawiana niewielka anizotropia w tym przypadku jest spowodowana warstwowaniem poziomym próbki węgla oraz spękaniami zorientowanymi równolegle do uwarstwienia. Rdzeń wycięty prostopadle do uwarstwienia posiadał mniej spękań (rys. 2), przez co prędkości fal w tej próbce były stosunkowo wysokie. Natomiast w dwóch pozostałych rdzeniach spękania mogły obniżyć prędkości fal, stąd niewielkie różnice w prędkościach fal pomiędzy próbkami i w konsekwencji niska anizotropia.

Oczywiście pojedynczy pomiar anizotropii (tak jak w tym przypadku) jest mało wiarygodny. Aby w pełni potwierdzić

Tabela 5. Składowe elastyczne oraz parametry Thomsena badanych próbek

Table 5. Elastic components and Thomsen parameters of measured samples

\begin{tabular}{|c|c|c|c|c|c|c|c|c|c|c|}
\hline Parametr & $\mathbf{C}_{33}$ & $\mathbf{C}_{11}$ & $\mathbf{C}_{44}$ & $\mathbf{C}_{66}$ & $\mathbf{C}_{13}$ & $\varepsilon$ & $\boldsymbol{\gamma}$ & $\sigma$ & $\boldsymbol{\eta}$ & $\boldsymbol{\delta}$ \\
\hline \hline Wartość & 7,24 & 7,56 & 2,04 & 2,26 & 3,50 & 0,022 & 0,055 & 0,237 & 0,073 & $-0,044$ \\
\hline
\end{tabular}
sformułowane powyżej wnioski, należałoby wykonać pomiary co najmniej na kilku - kilkunastu próbkach rdzeniowych wyciępotwierdzają dane mikrosejsmiczne (Kroplewski et al., 2019). Zatem niskie wskaźniki kruchości w przypadku węgli kamiennych nie oznaczają plastyczności skały w klasycznym tego słowa rozumieniu. Praktyka pokazuje, że w formacji o takich

tych w każdym z trzech kierunków. Artykuł ten należy zatem traktować jako wstęp do dalszych prac nad tym zagadnieniem, których wyniki zostaną opublikowane jako uzupełnienie tego artykułu. 
Tabela 6. Porównanie wybranych parametrów uzyskanych podczas badań z danymi dostępnymi w literaturze

Table 6. Comparison of selected parameters from measurements and from literature data

\begin{tabular}{|c|c|c|c|c|c|}
\hline Parametr & $\begin{array}{c}\text { Prezentowana praca } \\
\text { (Moska i Masłowski, 2019) }\end{array}$ & Qiuliang i De-hua, 2008 & Morcote et al., 2010 $^{\mathbf{2}}$ & Wu et al., 2015 $^{\mathbf{3}}$ & Qiong et al., 2016 $^{\mathbf{4}}$ \\
\hline \hline$\rho\left[\mathrm{g} / \mathrm{cm}^{3}\right]$ & $1,27-1,28$ & $1,36-1,44$ & $1,30-1,34$ & $1,45-1,61$ & - \\
\hline$V_{P}[\mathrm{~m} / \mathrm{s}]$ & $2378-2430$ & $2320-2430$ & ok. $2100-2600$ & $2220-2632$ & $2260-2540$ \\
\hline$V_{S}[\mathrm{~m} / \mathrm{s}]$ & $1261-1328$ & $1080-1220$ & ok. $950-1200$ & $1091-1382$ & $1060-1150$ \\
\hline$v[-]$ & $0,29-0,30$ & - & - & $0,27-0,35$ & - \\
\hline$E[\mathrm{GPa}]$ & $5,32-5,77$ & - & - & $4,62-8,05$ & $3,70-4,30$ \\
\hline$\varepsilon$ & 0,022 & $0,12-0,23$ & $0,08-0,11$ & - & - \\
\hline$\gamma$ & 0,055 & 0,05 & $0,025-0,03$ & - & - \\
\hline$\delta$ & $-0,044$ & $-0,04-0,01$ & - & - & - \\
\hline
\end{tabular}

${ }^{1}$ prędkości fal dla węgla nasyconego wodą, ciśnienie uszczelnienia $20 \mathrm{MPa}$. Anizotropia dla próbek nienasyconych, ciśnienie uszczelnienia $10 \mathrm{MPa}$

dla węgla bitumicznego przy ciśnieniu uszczelnienia $10 \mathrm{MPa}$

${ }^{3} \mathrm{~W}$ zależności od orientacji próbki równolegle lub prostopadle do uwarstwienia, ciśnienie uszczelnienia $10 \mathrm{MPa}$

${ }^{4}$ w zależności od ilości mikroporów w próbce, ciśnienie uszczelnienia $10 \mathrm{MPa}$

\section{Wnioski}

1. Artykuł prezentuje eksperymentalną próbę wyznaczenia parametrów anizotropii Thomsena w próbce węgla kamiennego z obszaru GZW. Badania wykonywano metodą trójrdzenikową Vernika. Rdzeniki posiadały widoczne uwarstwienie poziome oraz niewielkie spękania równolegle do uwarstwienia. Badania wykonywano na rdzeniach suchych, w temperaturze otoczenia, przy zadanym ciśnieniu uszczelnienia.

2. Prędkości fal P i S (odpowiednio 2378-2430 m/s i 1261$1328 \mathrm{~m} / \mathrm{s}$ ) oraz uzyskane dzięki nim dynamiczne moduły sprężystości (moduł Younga: 5,3-5,7 GPa, współczynnik Poissona: 0,29-0,30) okazały się zbliżone do wartości opisywanych w literaturze dla próbek węgla kamiennego bitumicznego testowanych w podobnych warunkach.

3. Badane próbki charakteryzowały się niewielką anizotropią poprzeczną oraz azymutalną, co potwierdzają współczynniki $K$ i $A$ zbliżone do jedności oraz parametry Thomsena $\varepsilon$, $\gamma, \delta$. Można przypuszczać, że anizotropia w tym przypadku była spowodowana warstwowaniem poziomym próbki węgla oraz spękaniami zorientowanymi równolegle do uwarstwienia.

4. Wskaźniki kruchości brittleness dla badanych próbek zawierały się w przedziale $22,7-23,9 \%$, co mogłoby wskazywać, że są to skały plastyczne o niskiej podatności na szczelinowanie. Jednakże struktura węgli kamiennych, tj. ich słaba konsolidacja oraz silne spękania, sprzyja otwieraniu się szczelin podczas zabiegu, dlatego nie należy ich rozpatrywać jako plastycznych w klasycznym rozumieniu odnoszącym się do zwięzłych skał mułowcowo-ilastych lub piaskowców.
5. W przyszłości planowane jest kontynuowanie badań na podstawie powyższego schematu dla większej liczby próbek z kilku kopalń GZW celem oszacowania poziomu anizotropii w zależności od składu macerałowego skały, dojrzałości termicznej, uwarstwienia i mikropęknięć oraz warunków pomiarów, takich jak ciśnienia, temperatury i nasycenie mediami.

Artykuł został opracowany na podstawie pracy statutowej pt. Badania anizotropii właściwości sprężystych w węglach kamiennych obszaru GZW - praca INiG - PIB na zlecenie MNiSW; nr zlecenia: 0042/KS/2019, nr archiwalny: DK-4100-0032/2019.

\section{Literatura}

Alramahi B., Sundberg M., 2012. Proppant embedment and conductivity of hydraulic fractures in shales. $46^{\text {th }}$ U.S. Rock Mechanics/ Geomechanics Symposium. ARMA 12-291.

Bała M., 2018. Obliczanie anizotropii Thomsena w łupkach gazonośnych basenu bałtyckiego na podstawie pomiarów geofizyki otworowej. Nafta-Gaz, 11: 796-801. DOI: 10.18668/NG.2018.11.03.

Ciechanowska M., Zalewska J., 2006. Anizotropia sprężystych właściwości skał. Materiały z konferencji Geopetrol, 587-600.

Fjar E., Holt R., Horsrund P., Raanen A., Risnes R., 2008. Petroleum related rock mechanics, second edition. Elsevier Science.

Garcia-Gonzalez M., Towle G., 2006. Measurements of elastic wave velocities in coal samples of differential rank. Boletin de Geologia, 28(1): 81-95.

Gonet A., Nagy S., Rybicki C., Siemek J., Stryczek S., Wiśniowski R., 2010. Technologia wydobycia metanu z pokładów węgla (CMB). Górnictwo i Geologia, 5(3): 5-25.

Grieser B., Bray J., 2007. Identification of production potential in unconventional reservoirs. Society of Petroleum Engineers. DOI: 10.2118/106623-MS.

Jureczka J. Zasoby metanu z pokładów węgla w Polsce. $<$ https:// www.pgi.gov.pl/psg-1/psg-2/informacja-i-szkolenia/wiadomoscisurowcowe/10856-zasoby-metanu-z-pokladow-wegla-w-polsce. html> (dostęp: 11.04.2019). 
Kasza P., 2013. Efektywne szczelinowanie łupków w Polsce. NaftaGaz, 11: 807-813.

Kasza P., 2019. Zabiegi hydraulicznego szczelinowania złóż niekonwencjonalnych i metody ich analizy. Prace Naukowe Instytutu Nafty i Gazu - Państwowego Instytutu Badawczego, 226: 1-147. DOI: 10.18668/PN2019.226.

Kroplewski Ł., Kasza P., Jureczka J., 2019. CBM Gilowice Project Applied fracturing technology and the obtained results. Workshops on best practices in coal mine methane capture and utilization. Turcja i Ukraina, 10-16.06.2019.

Kumar H., Mishra S., Mishra M., 2015. Experimental evaluation of geo mechanical properties of coal using sonic velocity. Advances in Agricultural, Biological \& Environmental Sciences, 2223.07.2015. Conference Paper. DOI: 10.15242/IICBE.C0715073.

Lo T., Coyner K., Toskoz M., 1985. Experimental determination of elastic anisotropy of Berea sandstone, Chicopee shale and Chelmsford granite. Geophysics, 51(1): 164-171. DOI: 10.1190/1.1442029.

Masłowski M., Kasza P., Czupski M., Wilk K., Moska R., 2019. Studies of fracture damage caused by the proppant embedment phenomenon in shale rock. Applied Science, 9(2190): 1-14. DOI: 10.3390/app9112190.

Morcote A., Mavko G., Prasad M., 2010. Dynamic elastic properties of coal. Geophysics, 75(6): E227-E234. DOI: 10.1190/1.3508874.

PIG - PIB, PGNiG, 2017. Projekt badawczy Gilowice - stymulacja produktywności metanu z pokładów węgla. $<$ http://orka.sejm. gov.pl/opinie8.nsf/nazwa/390_20171123/\$file/390_20171123. pdf> (dostęp: 10.04.2019).

Qiong L., Jie C., Jianjun H., 2016. Laboratory measurements of the acoustic velocity and elastic property of coal rocks and their link to micro-features. SEG International Exposition and $86^{\text {th }}$ Annual Meeting, 3359-3363. DOI: 10.1190/segam2016-13877215.1.

Qiuliang Y., De-hua H., 2008. Acoustic properties of coal from lab measurements. SEG Technical Program Expanded Abstracts, 27(1). DOI: $10.1190 / 1.3059254$.

Rickman R., Mullen M., Petre E., Grieser B., Kundert D., 2008. A practical use of shale petrophysics for stimulation design optimization: All shale plays are not clones of the Barnett Shale. Society of Petroleum Engineers. DOI: 10.2118/115258-MS.

Sone H., Zoback M., 2013. Mechanical properties of shale-gas reservoir rocks - Part 1: Static and dynamic elastic properties and anisotropy. Geophysics, 78(5): D381-D392. DOI: 10.1190/ GEO2013-0050.1.

Thomsen L., 1986. Weak elastic anisotropy. Geophysics, 51(10): 1954-1966. DOI: 10.1190/1.1442051.

Vernik L., 1993. Microcrack-inducted versus intrinsic elastic anisotropy in mature HC-source shales. Geophysics, 58(11), 1703-1706. DOI: $10.1190 / 1.1443385$.
Vernik L., Liu X., Nur A., 1994. Effect of kerogen on velocity anisotropy in source rock. SEG Technical Program Expanded Abstracts. DOI: 10.1190/1.1932086.

Vernik L., Nur A., 1992. Ultrasonic velocity and anisotropy of hydrocarbon source rock. Geophysics, 57(5), 727-735. DOI: 10.1190/1.1443462.

Wang Z., 2002a. Seismic anisotropy in sedimentary rocks, part 1: A single-plug laboratory method. Geophysics, 67(5), 1415-1422. DOI: $10.1190 / 1.1512787$.

Wang Z., 2002b. Seismic anisotropy in sedimentary rocks, part 2: Laboratory data. Geophysics, 67(5), 1423-1440. DOI: 10.1190/1.1512743.

Wu H., Dong S., Li D., Huang Y., Qi X., 2015. Experimental study on dynamic elastic parameters of coal samples. International Journal of Mining Science and Technology, 25, 447-452. DOI: 10.1016/j.ijmst.2015.03.019.

Yin H., 1992. Acoustic velocity and attenuation of rocks: Isotropy intrinsic anisotropy and stress inducted anisotropy. PhD thesis, Stanford University.

Yu G., Vozoff K., Durney D.W., 1993. The influence of confining pressure and water saturation on dynamic elastic properties of some Permian coals. Geophysics, 58(1), 30-38. DOI: 10.1190/1.1443349.

Zalewska J., Sikora G., Gąsior I., 2009. Laboratoryjne badania anizotropii sprężystych właściwości skał. Nafta-Gaz, 11, 669-677.

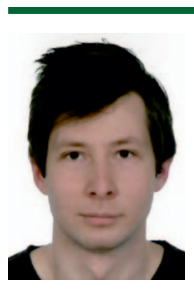

Mgr Rafał MOSKA

Asystent w Zakładzie Stymulacji Wydobycia Węglowodorów

Instytut Nafty i Gazu - Państwowy Instytut Badawczy ul. Lubicz $25 \mathrm{~A}$

31-503 Kraków

E-mail: rafal.moska@inig.pl

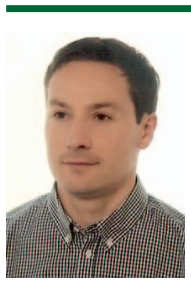

Mgr inż. Mateusz MASŁOWSKI

Asystent w Zakładzie Stymulacji Wydobycia

Węglowodorów

Instytut Nafty i Gazu - Państwowy Instytut Badawczy ul. Lubicz 25 A

31-503 Kraków

E-mail: mateusz.maslowski@inig.pl 